\section{Flower Bud Mortality and Salt Levels in Highbush Blueberry Fields Adjacent to Michigan Highways Treated with Deicing Salt}

\author{
Steven F. Berkheimer ${ }^{1}$, Jason K. Potter ${ }^{2}$, Jeffrey A. Andresen ${ }^{3}$, \\ and Eric J. Hanson ${ }^{1,4}$
}

AdDITIONAL INDEX WORDS. Vaccinium corymbosum, sodium chloride, salt spray, salt injury, global positioning system, GPS

SUMMARY. Some highbush blueberry (Vaccinium corymbosum) fields adjacent to Michigan roads exhibit abnormally high levels of winter flower bud mortality and twig dieback, even following relatively mild winters. This work was conducted to determine if this injury was caused by deicing salts (primarily sodium chloride) that are applied to adjacent roads and blown by the wind onto bushes. Flower bud mortality was recorded in the spring at several locations within six farms adjacent to divided highways treated with deicing salts. Four farms were east of highways (downwind of prevailing wind direction) and two were west (upwind) of highways. Each May for 3 years, the numbers of live and dead flower buds were counted on plants located varying distances from the highway. Bush position and distance from the highway were determined with global positioning system (GPS) equipment. Bud health was also assessed monthly during the winter. In fields located downwind of highways, bud mortality was consistently greatest close to the road and decreased with distance. Salt had an apparent effect on mortality 60 to $120 \mathrm{~m}$ from the highway, depending on the year. In fields west or upwind of highways, bud mortality was not consistently related to distance from the highway. Flower bud injury was evident by mid-January, and increased throughout the winter. Results indicated that wind-blown salt spray can cause considerable injury in blueberry fields close to salted roads.

$\mathrm{D}$ eicing salts are used widely in snow- and ice-prone climates to melt ice and keep road surfaces safe for travel. Several deicing materials are available for road application, but sodium chloride $(\mathrm{NaCl})$ is the most common because it is relatively effective and inexpensive. In Michigan, salt is applied repeatedly during the winter based on weather events. Annual applications on highways range from 26 to 35 tons per mile of 24 - $\mathrm{ft}$-wide road surface (Michigan Department of Transportation, 1993). Although the use of deicing salt helps maintain safe driving conditions, salt that moves off the road surface can contaminate surface water or ground water (Williams et al., 1999). Salt injury to

Michigan State University, East Lansing, MI 48824.

${ }^{1}$ Department of Horticulture, A388 Plant and Soil Sciences Building.

${ }^{2}$ Department of Fisheries and Wildlife, 322 Natural Resources Building.

${ }^{3}$ Department of Geography, 236 Geography Building.

${ }^{4}$ To whom reprint requests should be made; e-mail: hansone@msu.edu roadside vegetation is widely reported in northern areas of the United States (Barrick et al., 1979; Bowers and Hesterberg, 1976; Bryson and Barker, 2002; Davidson, 1970; Herrick, 1988; Sucoff, 1975), Canada (Hofstra et al., 1979; Northover, 1987), Europe (Bogemans et al., 1989; Buschbom, 1980; Pedersen et al., 2000), and the United Kingdom (Gibbs and Palmer, 1994; Thompson et al., 1986).

Deicing salts may leave roadways through surface runoff (Langille, 1976; Thompson et al., 1986) or as wind-blown spray or dust that is gen- erated by traffic (Sucoff, 1975). Soil inundation from runoff tends to be confined to within $10 \mathrm{~m}$ of the road and can cause severe dieback of tree crowns and branches or whole plants (Thompson and Rutter, 1986). In contrast, aerial spray typically causes browning of conifer needles, and twig and branch dieback. Spray injury to woody plants usually is not lethal, but often results in "witches broom" growth characterized by excessive branching (Davidson, 1970; Dirr, 1975; Lumis et al., 1973; Sucoff, 1975). Wind-blown spray may affect plants farther from roads than runoff. The quantity of salt spray leaving roadways may depend on the amount applied, traffic speed and volume, and weather conditions. The sensitivity of plant species to salt spray is not necessarily related to their tolerance to excess soil salt (Thompson and Rutter, 1986).

Michigan leads the U.S. in highbush blueberry production, annually producing an average of 75 million $\mathrm{lb}$ on 18,500 acres concentrated along the shore of Lake Michigan in southwest Michigan (Kleweno and Matthews, 2005). In 1999, Michigan growers began reporting excessive winter mortality to twigs and flower buds on plants close to salt-treated roads. Injury resulted in partial to complete loss of flower buds and fruiting potential. Vegetative growth and canopy development was delayed, but plants appeared normal by mid-summer. Berkheimer and Hanson (2006) studied whether this injury could be attributed to deicing salt by spraying potted bushes with salt solutions. Sprays caused similar injury, and also reduced the hardiness and increased cold injury to flower buds. Similar salt injury has been reported in lowbush blueberry ( $V$. angustifolium) fields adjacent to salted highways (Eaton et al., 1999) or bordering ocean bays (Eaton et al., 2004). The objective of the current

\begin{tabular}{llll}
\hline $\begin{array}{l}\text { Units } \\
\begin{array}{l}\text { To convert U.S. to SI, } \\
\text { multiply by }\end{array}\end{array}$ & U.S. unit & SI unit & $\begin{array}{l}\text { To convert SI to U.S., } \\
\text { multiply by }\end{array}$ \\
\hline 0.4047 & $\mathrm{acre}(\mathrm{s})$ & $\mathrm{ha}$ & $2.471 \mathrm{l}$ \\
29.5735 & $\mathrm{fl} \mathrm{oz}$ & $\mathrm{mL}$ & 0.0338 \\
0.3048 & $\mathrm{ft}$ & $\mathrm{m}$ & 3.2808 \\
2.54 & inch $(\mathrm{es})$ & $\mathrm{cm}$ & 0.3937 \\
0.4536 & $\mathrm{lb}$ & $\mathrm{kg}$ & 2.2046 \\
1.6093 & $\mathrm{mile}(\mathrm{s})$ & $\mathrm{km}$ & 0.6214 \\
1.6093 & $\mathrm{mph}$ & $\mathrm{km} \cdot \mathrm{h}^{-1}$ & 0.6214 \\
$1.1161 \times 10^{7}$ & $\mathrm{Oz} / \mathrm{inch}$ & $\mu \mathrm{gg} \cdot \mathrm{cm}^{-1}$ & $8.96 \times 10^{-8}$ \\
0.9072 & $\mathrm{ton}(\mathrm{s})$ & $\mathrm{Mg}$ & 1.1023 \\
$\left({ }^{\circ} \mathrm{F}-32\right) \div 1.8$ & ${ }^{\circ} \mathrm{F}$ & ${ }^{\circ} \mathrm{C}$ & $\left(1.8 \times{ }^{\circ} \mathrm{C}\right)+32$ \\
& & &
\end{tabular}


study was to describe the extent and distribution of injury and salt deposition in blueberry fields bordering salted roads in western Michigan.

\section{Materials and methods}

Flower bud damage was surveyed on six blueberry farms in southwestern Michigan. Four farms were located just east of divided highways, and two farms were just west of a divided highway. 'Jersey' was the predominant variety, but some 'Bluecrop' and 'Rubel' plants were also present. On each farm, between 13 and 105 sampling locations were chosen that were on a rough grid at varying distances from the road. In May 2002, 2003, and 2004, as bushes were approaching bloom, five twigs were selected from each of two adjacent bushes at each field location. Twigs were selected from the side of the plants nearest the road, in order to reduce variability. The number of dead and live flower buds were recorded. Assessments were performed during bloom, so that dead buds could be distinguished from live buds. The GPS coordinates of each sampling location were determined with a TSCl Datalogger (Trimble Navigation Limited, Sunnyvale, Calif.), and were used to calculate the distance to the highway. The relationships between bud mortality and distance to the highway were determined by regression analyses (TableCurve 2D, version 2.00; Systat Software, San Rafael, Calif.) using pooled data (by year) from farms east of the highway and those west of the highway. Regression models were generated by TableCurve to describe the relationships between distance from the highway and percent flower bud mortality. The best-fitting models were selected based on the highest $\mathrm{R}^{2}$ and probability values. The probability values were computed for each model using the PROC NLIN command of SAS (version 8.0; SAS Institute, Cary, N.C.). Farm maps were constructed from the GPS coordinates using ArcView (version 3.2; ESRI, Redlands, Calif.) to illustrate injury levels by position.

Additional twigs were sampled from Farm 1 to determine how salt deposition and injury to buds varied during the winter months. Fifteen twigs were sampled from each of eight locations, varying from 34 to $116 \mathrm{~m}$ from the road, in Jan. and Mar. 2002, and Jan., Feb., and Mar. 2003. Twigs were placed in plastic bags and on ice, transported to East Lansing, Mich., and shortened to $10 \mathrm{~cm}$. The five twig samples were placed in 50 -mL centrifuge tubes containing $20 \mathrm{~mL}$ of double deionized water, capped, and inverted 10 times to rinse off surface salts. The rinsate was poured into separate tubes, and the electrical conductivity (EC) was measured with an EC meter (Orion Research, Boston). The EC reading was multiplied by 0.584 to convert total salt to micrograms $\mathrm{NaCl}$ equivalents (Soil and Plant Analysis Council, 1992), and final amounts were expressed as micrograms $\mathrm{NaCl}$ percentimeter stem length. Twigs were then wrapped in moist paper towels in plastic bags, held at $18{ }^{\circ} \mathrm{C}$ for $5 \mathrm{~d}$, and then dissected to distinguish live and dead buds. Mean flower bud mortality was computed by dividing the number of dead buds from all twigs sampled from each field location by the total number of flower buds and multiplying this number by $100 \%$.

Hourly temperature and precipitation data were obtained from an automated weather station in West
Olive, Mich. (less than 20 miles from each surveyed farm), which was part of the Michigan Automated Weather Network (Michigan State Climatologist's Office). Hourly wind speed and direction data were obtained from a National Weather Service observing station at the Muskegon County airport, also within 20 miles from surveyed farms.

\section{Results and discussion}

Farms east of the highway had a mean (across 3 years) flower bud mortality of $36 \%$, whereas farms west of the highway averaged 19\% (Table 1). Since data were not normally distributed, median values were also reported (Table 1). Median flower bud mortality across all years was $25 \%$ and $15 \%$ east and west of the highway, respectively. When the relationship between proximity to the highway and flower bud mortality was examined by regression analysis, farms east of the highway showed consistent decreasing mortality with increasing distance to the road (Fig. 1), whereas no such tendency was observed at farms west of the highway (Fig. 2). On farms east of the highway, mortality was generally higher 60 to $120 \mathrm{~m}$ from the road compared to farther away (Fig. 1).

Flower bud mortality levels over 3 years are plotted graphically for one farm east of the highway (Fig. 3) to illustrate spatial variability across one field. Figure 3 illustrates that mortality was greatest close to the divided highway, but that injury may also have been affected by proximity to a secondary road south of the farm. This may be partly why the regression functions in Fig. I did not explain higher percentages of the variation in flower bud mortality $\left(\mathrm{R}^{2}\right.$ values ranged from 0.16 to 0.63 ). One farm west of the highway

Table 1. The mean, median, and range of flower bud mortality in four highbush blueberry farms located east of divided highways and two farms west of highways in southwestern Michigan.

\begin{tabular}{|c|c|c|c|c|c|c|c|c|c|}
\hline & \multicolumn{9}{|c|}{ Flower bud mortality (\%) } \\
\hline & \multicolumn{3}{|c|}{2002} & \multicolumn{3}{|c|}{2003} & \multicolumn{3}{|c|}{2004} \\
\hline & Mean (n) & Median & Range & Mean (n) & Median & Range & Mean (n) & Median & Range \\
\hline & \multicolumn{9}{|c|}{ Farms east of highway } \\
\hline 1 & $3(105)$ & 0 & $0-67$ & $45(40)$ & 39 & $0-100$ & $44(104)$ & 20 & $0-100$ \\
\hline 2 & $22(55)$ & 4 & $0-93$ & $48(36)$ & 34 & $0-100$ & $19(55)$ & 4 & $0-100$ \\
\hline \multicolumn{10}{|c|}{ Farms west of highway } \\
\hline 5 & $0(13)$ & 0 & 0 & $35(13)$ & 46 & $2-100$ & $25(13)$ & 15 & $0-67$ \\
\hline 6 & $3(31)$ & 2 & $0-21$ & $29(15)$ & 17 & $0-92$ & $16(31)$ & 10 & $0-100$ \\
\hline
\end{tabular}




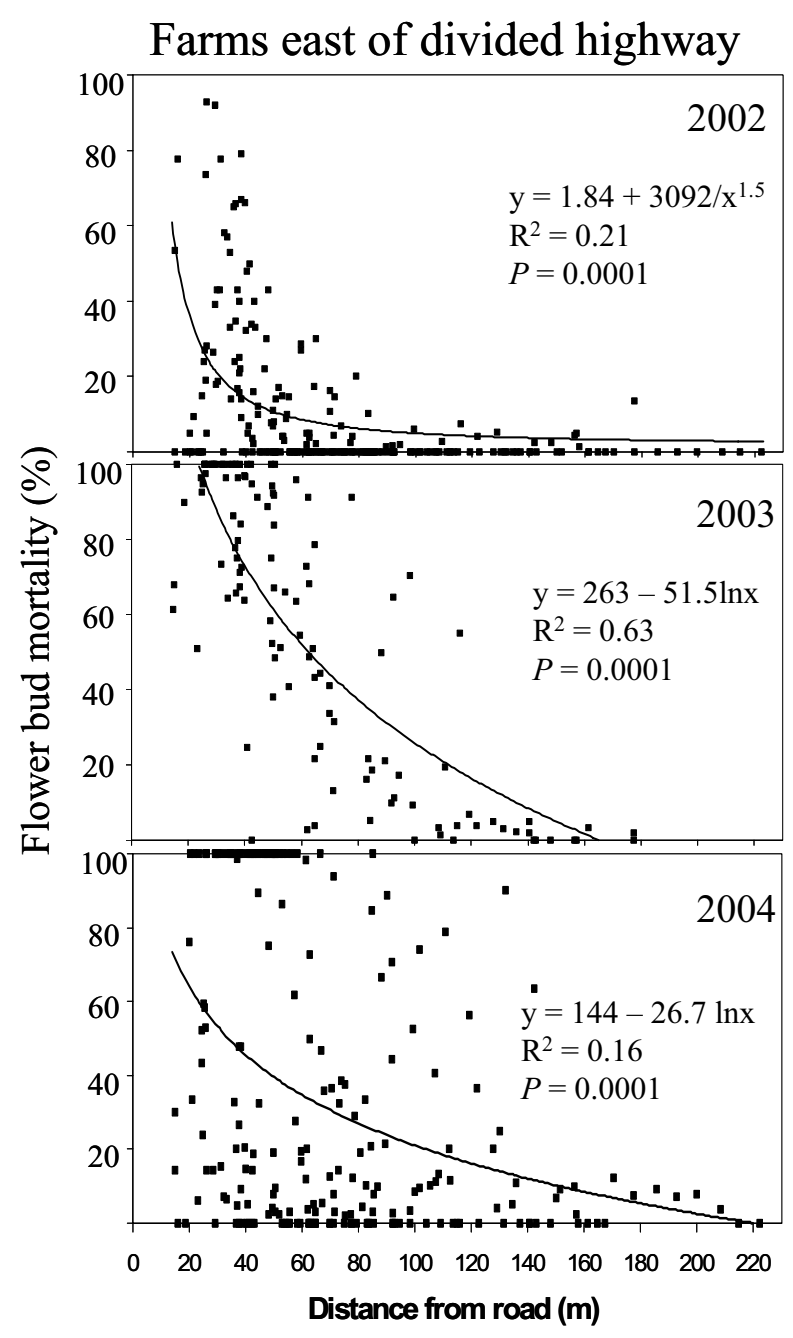

Fig. 1. Relationship between percent flower bud mortality in May (y) and distance from highways $(x)$ on four highbush blueberry farms located east of divided highways in southwest Michigan, in 2002, 2003, and 2003 ( $1 \mathrm{~m}=$ $3.2808 \mathrm{ft})$.

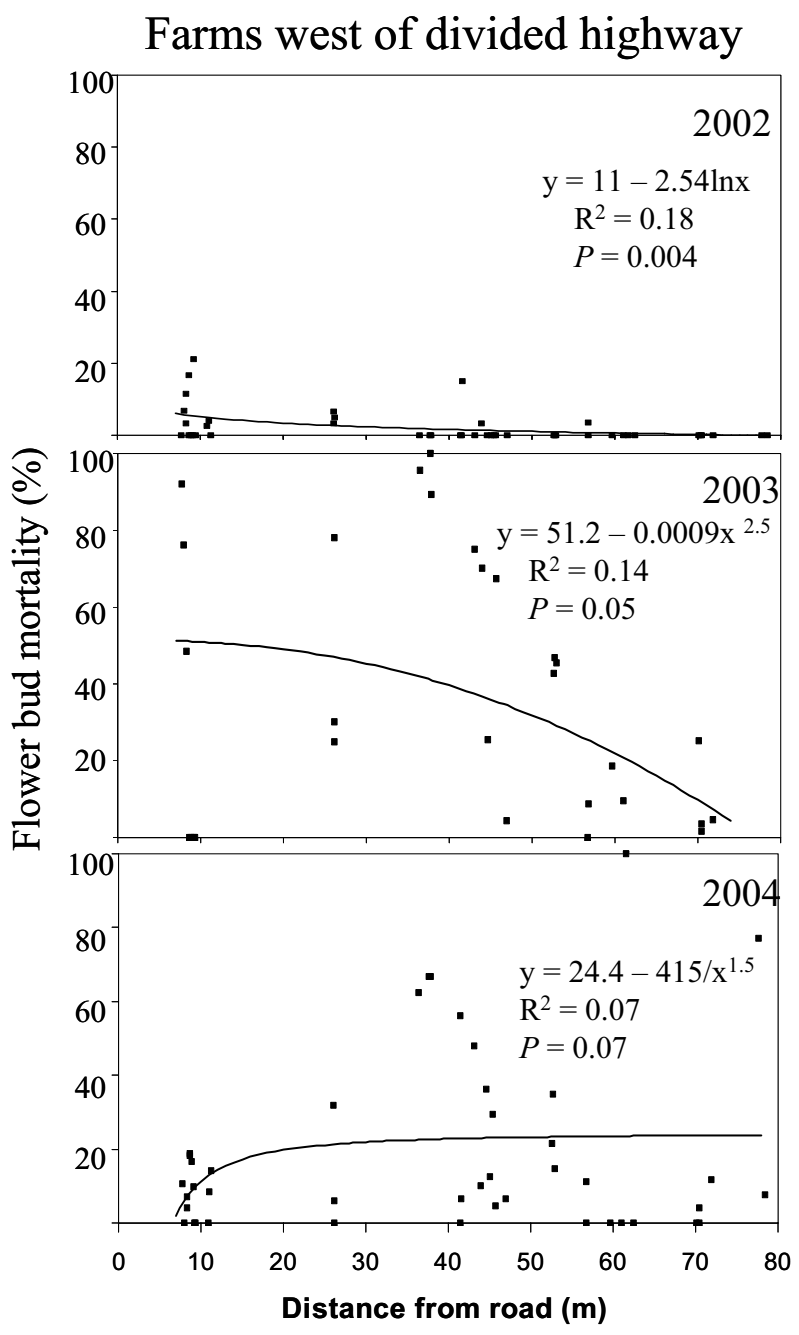

Fig. 2. Relationship between percent flower bud mortality in May (y) and distance from the highways $(x)$ on two highbush blueberry farms located west of divided highways in southwest Michigan, in 2002, 2003, and 2003 (1 $\mathrm{m}=3.2808 \mathrm{ft}$ ). also bordered a secondary road that appeared to affect mortality (data not shown). Woodlots immediately north of Farms 1 and 2 and south of Farm 3 may have shielded some nearby plants from salt when winds were moving from the northwest or southwest.

Flower bud mortality and salt deposition levels were recorded monthly on one farm east of the highway (Fig. 4). Injury appeared to be cumulative over time rather than the result of a single event. In contrast, salt residues on twigs did not accumulate with each subsequent sampling during the last two winters (Fig. 4). For example, residues decreased from $39 \mu \mathrm{g} \cdot \mathrm{cm}^{-1}$ shoot tissue in Feb. 2003 to $7 \mu \mathrm{g} \cdot \mathrm{cm}^{-1}$ 1 month later. Although precipitation could rinse residues from twigs, weather data recorded about $10 \mathrm{~km}$ away indicated precipitation between these sampling dates was minimal. Rain would be expected to rinse salt from twigs (Eaton et al., 1999), whereas dry snow that did not adhere to the twigs may not. We estimated salt levels (Fig. 4) based on electrical conductivity rather than analyzing for sodium $\left(\mathrm{Na}^{+}\right)$and chloride $\left(\mathrm{Cl}^{-}\right)$specifically, so it is not known whether all of the electrolytes rinsed from twigs originated from road salt. However, Eaton et al. (1999) studied salt residues on lowbush blueberry twigs by analyzing for $\mathrm{Cl}^{-}$specifically, and showed that salt residues increased linearly with proximity to a salted highway.

Prevailing winds in this region during the winter season are from west to east (Eichenlaub et al., 1990). Hourly wind direction and speed were recorded in Muskegon, Mich., each year from 1 Dec. and 15 Mar. When wind speeds were moderate to high $(\geq 10 \mathrm{mph})$, direction was eastward (to the northeast, east, or southeast) $84 \%, 78 \%$, and $70 \%$ of the time, during the 2001-02,2002-03, and 2003-04 winter seasons, respectively. Patterns of injury in farms were generally consistent with expected windborne movement of salts off road surfaces.

Salt appears to injure blueberry flower buds by reducing cold hardiness (Berkheimer and Hanson, 2006). Exposure to $\mathrm{NaCl}$ sprays also decreased the cold hardiness of several other woody plant species (Sucoff and Hong,1976; Sucoff et al.,1976). Greatest injury is expected when buds are exposed to high salt residues and cold temperatures. Winter tempera- 

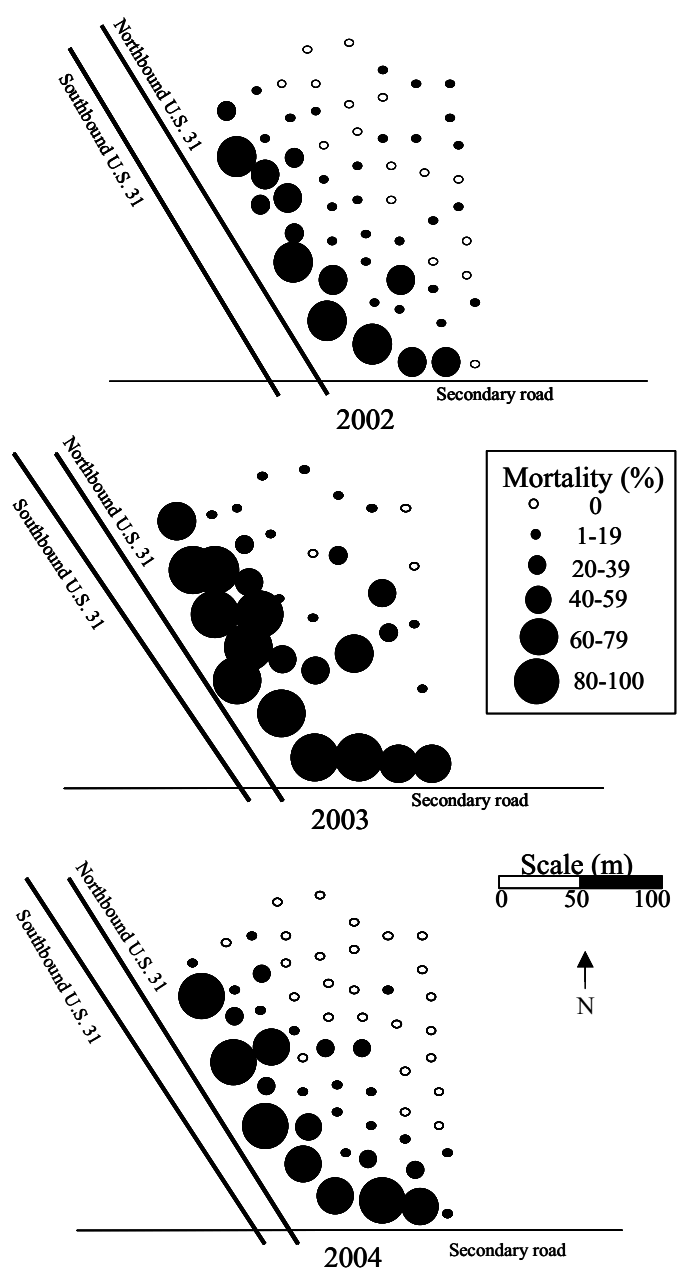

Fig. 3. Percent flower bud mortality on highbush blueberry Farm 1, Ottawa County, Mich., in May 2002, 2003, and 2004, illustrating observation locations relative to adjacent roads $(1 \mathrm{~m}=3.2808 \mathrm{ft})$.

tures during this study were normal to above normal, based on climatological records (National Oceanic and Atmospheric Administration, 2005) and annual minimum temperatures for this region(USDA Plant Hardiness Zone 6, average minimum temperature -18 to $\left.-23^{\circ} \mathrm{C}\right)$. The $2001-02$ winter was the mildest, with mean seasonal (December-February) temperatures $4.7^{\circ} \mathrm{C}$ above normal and daily temperatures falling below $-15{ }^{\circ} \mathrm{C}$ only once on 2 Jan. Temperatures during the second and third seasons were closer to normal (mean seasonal departures of +0.06 ${ }^{\circ} \mathrm{C}$ and $+1.1{ }^{\circ} \mathrm{C}$, respectively. Temperatures fell below $-15^{\circ} \mathrm{C}$ five times during the 2002-03 winter, and below $-20{ }^{\circ} \mathrm{C}$ three times during the 2003-04 winter. Overall flower bud mortality was lowest following the mild 2001-02 winter (mean of $10 \%$ ), and higher during the colder second (52\%) and third $(28 \%)$ seasons (Table 1$)$. Higher

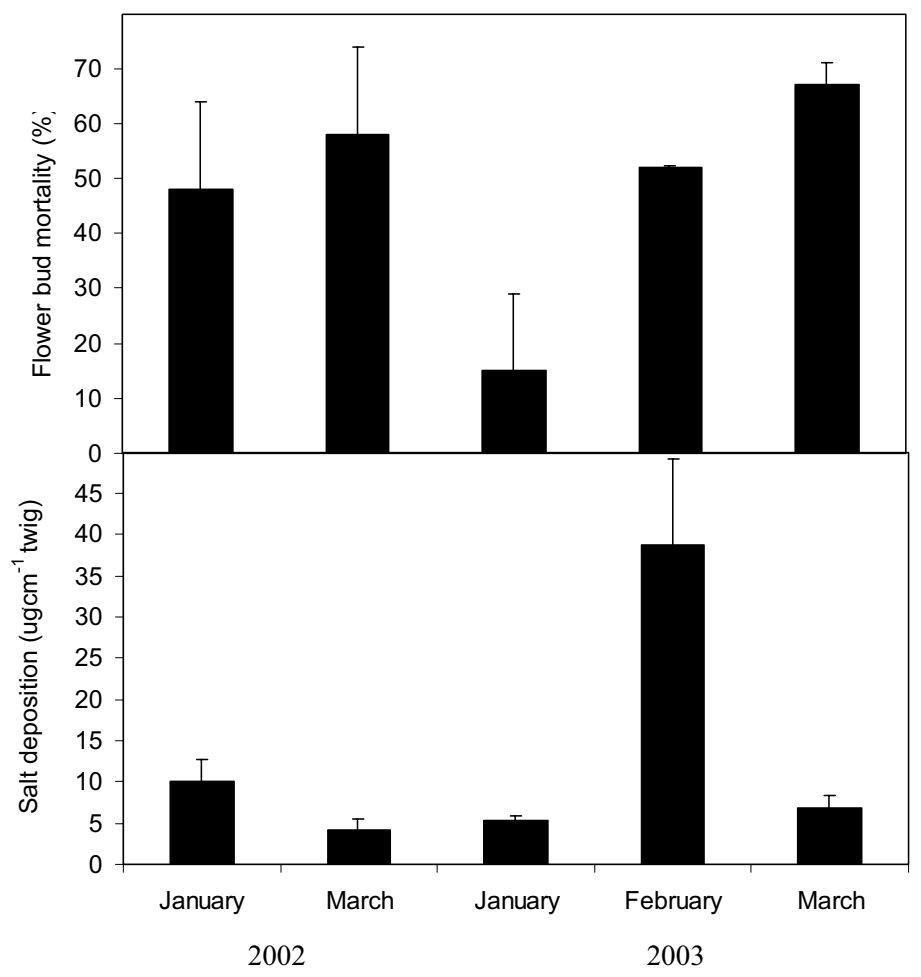

Fig. 4. Percent flower bud mortality (A) and salt deposition on twigs (B) by month, at highbush blueberry Farm 1, Ottawa County, Mich., 2002 and $2003\left(1 \mu \mathrm{g} \cdot \mathrm{cm}^{-1}=8.96 \times 10^{-8} \mathrm{oz} /\right.$ inch). Bars represent SE.

bud mortality would be expected during a cold winter when normal lethal temperatures are approached. Lethal temperatures for buds of northern highbush blueberries range from -22 to $-28{ }^{\circ} \mathrm{C}$ in mid-winter (Bittenbender and Howell, 1976), but vary by variety and fluctuate during the winter (Bittenbender and Howell, 1975). Salt spray appeared to affect bushes $60 \mathrm{~m}$ from the highway during the mild 2001-02 winter, but injury was apparent as far as $120 \mathrm{~m}$ during the second two, colder seasons (Fig.1).

Traffic volume, speed, and type (cars, trucks) might affect damage to roadside vegetation (Sucoff, 1975) because passing vehicles generate salt spray and dust that can move onto plants. These surveyed fields bordered a divided highway that carried a relatively large volume of traffic at higher speeds and with a significant number of trucks. Fields adjacent to secondary roads with lower vehicle numbers and speeds might be exposed to less salt and sustain less damage. Salt use rates were not available for these study locations, but Ottawa County Road
Commission personnel indicate that divided highways typically receive more salt than secondary roads, which would also increase the risk of injury.

The primary observed effect of salt exposure in this survey was flower bud mortality and twig dieback. However, on two farms east of the highway, plants nearest to the road exhibited more severe symptoms. Some plants had died while others had numerous dead and injured canes with extensive dieback. These severe symptoms are similar to those observed when the roots of potted plants were inundated with salt solutions (Berkheimer and Hanson, 2006), and suggest that plants exposed annually to high levels of spray may accumulate salt in tissues or soils, decreasing their tolerance in subsequent years.

\section{Conclusion}

These field observations indicate that airborne wind-blown deicing salts $(\mathrm{NaCl})$ can cause considerable loss of blueberry flower buds in fields next to Michigan highways. This conclusion is consistent with reports on lowbush blueberries (Eaton et al., 1999) and other roadside woody plants (Bryson and Barker, 2002; Hofstra and Hall, 
1971; Lumis et al., 1976; Pedersen et al., 2000; Sucoff, 1975; Thompson and Rutter, 1986). Fields at highest risk are those downwind of heavily traveled roads that are treated regularly with salt. Injury may extend as much as 120 $\mathrm{m}$ from the road, and is accentuated by cold temperatures.

\section{Literature cited}

Barrick, W.E., J.A. Flore, and H. Davidson. 1979. Deicing salt spray injury in selected Pinus spp. J. Amer. Soc. Hort. Sci. 104:617-622.

Berkheimer, S.F. and E.J. Hanson. 2006. Deicing salts reduce cold hardiness and increase flower bud mortality of highbush blueberry (Vaccinium corymbosum). J. Amer. Soc. Hort. Sci. 131:11-16.

Bittenbender, H.C. and G.S. Howell. 1975. Predictive environmental and phenological components of flower bud hardiness in highbush blueberry. HortScience 10:409-411.

Bittenbender, H.C. and G.S. Howell. 1976. Cold hardiness of flower buds from selected highbush blueberry cultivars (Vaccinium australe Small). J. Amer. Soc. Hort. Sci. 101:135-139.

Bogemans, J., L. Neirinckx, and J.M. Stassart. 1989. Effect of deicing chloride salts on ion accumulation in spruce [Picea abies (L.) sp.]. Plant Soil 113:3-11.

Bowers, M.C. and J.H. Hesterberg. 1976. Environmental implications of highway deicing agents on white pine in Marquette County, Michigan. Michigan Botanist $15: 75-89$.

Bryson, G.M. and A.V. Barker. 2002. Sodium accumulation in soils and plants along Massachusetts's roadsides. Commun. Soil Sci. Plant Anal. 33:67-78.

Buschbom, U. 1980. Experiences with de-icing salts in W. Germany. European J. For. Pathol. 10:349-353.

Davidson, H. 1970. Pine mortality along Michigan highways. HortScience 5:12-13.

Dirr, M.A. 1975. Effects of salts and salt application methods on english ivy. HortScience 10:182-184.
Eaton, L.J., J. Hoyle, and A. King. 1999. Effect of deicing salt on lowbush blueberry flowering and yield. Can. J. Plant Sci. 79:125-128.

Eaton, L.J., K.R. Sanderson, and J. Hoyle. 2004. Effects of salt deposition from salt water spray on lowbush blueberry shoots. Small Fruits Rev. 3:95-103.

Eichenlaub, V.L., J.R. Harman, F.V. Nurnberger, and H.J. Stolle. 1990. The climatic atlas of Michigan. Univ. of Notre Dame Press, Notre Dame, Ind.

Gibbs, J.N. and C.A. Palmer. 1994. A survey of damage to roadside trees in London caused by the application of de-icing salt during the 1990/91 winter. Arboriculture J. 18:321-343.

Herrick, G.T. 1988. Relationships between soil salinity, sap sugar concentrations, and health of declining roadside sugar maples (Acer saccharum). Ohio J. Sci. 88:192-194.

Hofstra, G. and R. Hall. 1971. Injury to roadside trees: Leafinjury on pine and white cedar in relation to foliar levels of sodium and chloride. Can. J. Bot. 49:613-622.

Hofstra, G., R. Hall, and G.P. Lumis. 1979. Studies of salt-induced damage to roadside plants in Ontario. Arboriculture J. 5:25-31.

Kleweno, D.D. and V. Matthews. 2005. Michigan agricultural statistics 2004-2005. Michigan Dept. Agr., Lansing.

Langille, A.R. 1976. One season's salt accumulation in soil and trees adjacent to a highway. HortScience 11:575-576.

Lumis, G.P., G. Hofstra, and R. Hall. 1973. Sensitivity of roadside trees and shrubs to aerial drift of deicing salt. HortScience $8: 475-477$.

Lumis, G.P., G. Hofstra, and R. Hall. 1976. Roadside woody plant susceptibility to sodium and chloride accumulation during winter and spring. Can. J. Plant Sci. 56:853-859.

Michigan Department of Transportation. 1993. The use of selected deicing materials on Michigan roads: Environmental and economic impacts. Public Sector Consultants with Michigan Dept. of Transportation, Lansing.
Michigan State Climatologist's Office. 2006. Michigan automated weather network. 24 Feb. 2006. <http://www. agweather.geo.msu.edu/mawn>.

National Oceanic and Atmospheric Administration. 2005. Climate summary of the day. Natl. Oceanic and Atmospheric Administration/Natl. Environ. Satellite, Data and Info. Serv., Natl. Climatic Data Ctr., Asheville, N.C.

Northover, J. 1987. NaCl injury to dormant roadside peach trees and its effect on the incidence of infections by Leucostoma spp. Phytopathology 77:835-840.

Pedersen, L.B., T.B. Randrup, and M. Ingerslev. 2000. Effects of road distance and protective measures on deicing $\mathrm{NaCl}$ deposition and soil solution chemistry in planted median strips. J. Arboriculture $26: 238-244$

Soil and Plant Analysis Council, Inc. 1992. Handbook on reference methods for soil analysis. Soil and Plant Analysis Council, Georgia Univ. Sta., Athens.

Sucoff, E. 1975. Effect of deicing salts on woody vegetation along Minnesota roads; Final report, 1975. Investigation No. 636, Minn. Agr. Exp. Sta. Tech. Bul. 303.

Sucoff, E. and S.G. Hong. 1976. Effects of $\mathrm{NaCl}$ on cold-hardiness of Malus spp. and Syringa vulgaris. Can. J. Bot. 54:2816-2819.

Sucoff, E., S.G. Hong, and A. Wood. 1976. $\mathrm{NaCl}$ and twig dieback along highways and cold hardiness of highway versus garden twigs. Can. J. Bot. 54:2268-2274.

Thompson, J.R. and A.J. Rutter. 1986. The salinity of motorway soils. IV. Effects of sodium chloride on some native British shrub species, and the possibility of establishing shrubs on the central reserves of motorways. J. Appl. Ecol. 23:299-315.

Thompson, J.R., A.J. Rutter, and P.S. Ridout. 1986. The salinity of motorway soils I. Variation in time and between regions in the salinity of soils on central reserves. J. Appl. Ecol. 23:251-267.

Williams, D.D., N.E. Williams, and Y. Cao. 1999. Road salt contamination of groundwater in a major metropolitan area and development of a biological index to monitor its impact. Water Res. 34:127-138. 